\title{
Research on the Evaluation of Supporting Ability of "Double-First Class"University Libraries Based on the Principal Component Analysis and Cluster Analysis
}

\author{
Xuhui Ding*, Yingfei Wang ${ }^{\mathrm{a}}$ \\ School of Business Administration, Hohai University, Changzhou 213022, China \\ ${ }^{*}$ Corresponding author e-mail: dingxh@hhu.edu.cn, ${ }^{a} 510558867 @ q q . c o m$
}

\begin{abstract}
Based on the data at the end of 2016 and selecting 12 variables such as building area and paper resource purchase fee, this paper uses principal component analysis and cluster analysis to evaluate the support ability and overall strength of 42 universities and colleges under "double-first class" construction. At last, ranking and classifying the university libraries according to the research results. This study has shown that the number of staff members, the purchase fee of electronic resources, paper resources, literature resources, the number of published paper and the number of paper resources are the main factors affecting the construction of university libraries. The gap in support ability among university libraries in the same region, different provinces and cities, and different types are obvious; the imbalance of libraries' own strength leads to their inefficiency; the strength of university libraries does not match the strength of scientific research. It is recommended that universities and colleges should allocate funds reasonably, increase the investment and attention in libraries, and strengthen exchanges and cooperation between university libraries in and between regions.
\end{abstract}

KEYWORDS: double-first class, university libraries, principal component analysis, cluster analysis

\section{Introduction}

University libraries are important institutions aimed at providing information and related services for university teaching and scientific research [1]. In the 1970s, Eliot, the President of Harvard University called the library "the heart of the university" [2]. In the report of the 19th National Congress of the Communist Party of China, Comrade Xi Jinping pointed out that it is necessary to speed up the construction of world-class universities and first-class disciplines, strengthen the cultivation of talents and introduction of resources in universities and colleges, and the 
construction of world-class universities and first-class disciplines cannot be done without the support of university libraries. Taking 42 "double-first class" universities and colleges for an example, the total area of library buildings is about 240,000 square meters, along with nearly 100 million paper resources. However, the utilization efficiency of libraries sometimes cannot match the development speed of universities and colleges, and there are problems such as low resource utilization rate and loose management, which does not make the library really play its role. There is a significant correlation between the core competitiveness of university libraries with the teaching level and scientific research ability of universities and colleges (Lin Kequan [1], 2014). However, the development level of Chinese university libraries is quite different. Most libraries cannot effectively use their funds, and financial support has not been completely transformed into the library's own strength. There is a large gap in the performance of university libraries in comprehensive, science, engineering, and normal universities and colleges, and the development is uneven (Jiang Yumei [2], 2014). Therefore, it is necessary to conduct customer observation and evaluation on the efficiency of university libraries, so as to provide reasonable suggestions on improving the input-output ratio of libraries, rationally utilizing existing resources, and improving resource utilization efficiency.

\section{Research Methods and Indicators Selection}

\subsection{Research Methods}

The principal component analysis is to use the idea of dimensionality reduction to transform multiple indicators into a few comprehensive indicators, each of which can reflect most of the information of the original variables, and the information contained is not repeated. First, the data is standardized to remove the influence of different dimensions on the data values; assuming that the original data $\mathrm{X}$ has $\mathrm{p}$ observations, $\mathrm{n}$ variables, the covariance matrix is calculated by formula (1), as well as the eigenvalue $\lambda_{1}, \lambda_{2}, \ldots \lambda_{n}$, the eigenvector corresponding to the eigenvalue is the eigenvalue and eigenvector of the main component's load factor aij; finally, the principal component number is determined by the cumulative contribution rate, and the score of observation sample on the principal component $\mathrm{Yi}$ is calculated by the formula (2).

$$
\begin{aligned}
V_{i j} & =\frac{1}{p-1} \sum_{k=1}^{p}\left(x_{k i}-\overline{x_{i}}\right)\left(x_{k j}-\overline{x_{j}}\right) \\
Y_{i} & =a_{i 1} x_{1}+a_{i 2} x_{2}+\ldots+a_{i n} x_{n}
\end{aligned}
$$

The cluster analysis is based on the basic characteristics of data, to calculate the internal correlation among the data, mainly through the calculation of some statistical indicators, to reflect the degree of similarity between the reaction data. The basic principle of cluster analysis is to calculate the distance between two of all variables, and classify the variables according to the distance. First, classify all the

\section{Published by Francis Academic Press, UK}


samples into one class. For data containing n variables, include n classes. Secondly, calculate the distance between any two of the above $n$ classes. According to the principle that the minimum distance is one class, the two classes with closer distance are clustered into one class, and this is the n-1 class. And so on, the two classes with the smallest merge distance are clustered into one class, until all the data are classified into one class [3]. In this paper, first calculate the Euclidean distance between different variables, as it can be seen from equation (3), and then perform cluster analysis.

$$
\mathrm{d}\left(\overrightarrow{x_{i}}, \overrightarrow{x_{j}}\right)=\sqrt{\sum_{k=1}^{p}\left(x_{i k}-x_{j k}\right)^{2}}
$$

\subsection{Data Selection}

The supporting ability of university libraries is mainly reflected in the input and output. In the past, most of the research conducted indicators selection from only one aspect, such as scientific research strength, thesis index, service quality, etc. rarely carried out comprehensive research on various indicators. Gao Haitao et al. [4] evaluated universtiy libraries from the perspective of service quality. Liang $\mathrm{Ru}$ [5] established a system from funds, staff, facilities investment, information services, teaching and research. In this paper, the input indicators are the area of the building, the number of staff, the total annual funds, etc., the output indicators are the number of published papers, etc. the quantity and quality of library resources are also taken into consideration, as shown in Table 1 . The relevant data comes from University Library of the Ministry of Education's fact database and the official website of the university. The research selects the data at the end of 2016, and some missing data will be replaced or smoothed by data from similar years.

The selection of indicators is as follows: (1) The building area is one of the basic indicators of library construction, and it is an important place to store a large amount of paper resources and large-capacity storage for storing electronic databases; (2) Library seats are the main place for students to learn by themselves. The number of seats should meet the needs of students in colleges and universities; (3) The number of hours of opening in weeks can reflect the length of service provided by the library; (4) The number of staff is directly related to the service and management quality of the university library; (5)The purchase of literature resources and total annual funds can show the investment of library resources in colleges and universities, whether they pay attention to the resources construction of libraries; (6) The more developed the economy of the city, the more attention is paid to education, and the more funds are invested; (7) The number of paper published reflects the overall scientific research level and ability of the library, which is closely related to the scientific research level of the university [6]; 8) The amount of paper resources and electronic resources can measure the level of document construction [7], which intuitively reflects the achievements of the university in the basic resources construction and

\section{Published by Francis Academic Press, UK}


contribution to university research capacity; (9) The number of students can estimate the approximate number of visitors to the library and its swipe.

Table 1 Evaluation indicators of supporting ability of "double first-class" university libraries

\begin{tabular}{|c|c|c|c|c|c|}
\hline Code & Indicator name & Code & Indicator name & Code & Indicator name \\
\hline X1 & Building area & X6 & $\begin{array}{c}\text { Annual total } \\
\text { funding }\end{array}$ & X11 & $\begin{array}{c}\text { Paper resources } \\
\text { number }\end{array}$ \\
\hline X2 & Number of staff & X7 & $\begin{array}{c}\text { Library seat } \\
\text { number }\end{array}$ & X12 & $\begin{array}{c}\text { Chinese \& foreign } \\
\text { databases }\end{array}$ \\
\hline X3 & $\begin{array}{c}\text { Electronic } \\
\text { resource fee }\end{array}$ & X8 & City GDP & X13 & $\begin{array}{c}\text { Electronic resources } \\
\text { number }\end{array}$ \\
\hline X4 & Paper resource fee & X9 & $\begin{array}{c}\text { Weekly opening } \\
\text { hours }\end{array}$ & X14 & $\begin{array}{c}\text { Current student } \\
\text { quantity }\end{array}$ \\
\hline X5 & $\begin{array}{c}\text { Document } \\
\text { resource fee }\end{array}$ & $\mathrm{X} 10$ & $\begin{array}{c}\text { Paper published } \\
\text { number }\end{array}$ & & \\
\hline
\end{tabular}

\section{Empirical Measurement and Results Analysis}

\subsection{Results of Principal Component Analysis}

Table 2 Description of eigenvalues and contributions of various indicators in in library support

\begin{tabular}{|c|c|c|c|c|c|}
\hline Variable & Eigenvalues & $\begin{array}{c}\text { Cumulative } \\
\text { contribution rate(\%) }\end{array}$ & Variable & Eigenvalues & $\begin{array}{c}\text { Cumulative } \\
\text { contribution rate(\%) }\end{array}$ \\
\hline 1 & 4.835 & 34.54 & 8 & 0.510 & 90.01 \\
\hline 2 & 2.025 & 49.00 & 9 & 0.416 & 92.98 \\
\hline 3 & 1.659 & 60.86 & 10 & 0.314 & 95.23 \\
\hline 4 & 1.178 & 69.27 & 11 & 0.227 & 96.85 \\
\hline 5 & 0.984 & 76.30 & 12 & 0.194 & 98.24 \\
\hline 6 & 0.783 & 81.89 & 13 & 0.150 & 99.30 \\
\hline 7 & 0.628 & 86.38 & 14 & 0.097 & 100.00 \\
\hline
\end{tabular}

Based on the results of the above principal component analysis, the number of staff members, the purchase fee of electronic resources, paper resources, literature resources, the number of published paper and the number of paper resources have contributed greatly to the research, and the cumulative contribution rate of six indicators is $81.89 \%$, which can better explain the original variables. Other variables are also the evaluation factors, which can give assistance to the main six factors, and help better evaluate the support ability of universities and colleges under "doublefirst class" construction. According to data, we can get score of every main component. The result of the calculation is divided into two tables, shown in Table 3 
and 4.At the same time, according to the scores of different variables in different components, the scores of "double-first class" university libraries can be calculated and sorted. The specific results are shown in Table 5.

The research results show that (1) Among the "double-first class" colleges and universities, the B-class university libraries are slightly behind the A-class universities, and the B-class colleges and universities have weaker support for the libraries, which makes the library develop slowly, such as the total funding of the library of Xinjiang University has a large difference with other colleges and universities, and the number of paper resources and electronic resources is seriously insufficient, which does not meet the demands of teachers and students. (2) The top 10 universities are mostly eastern university libraries, mainly in Beijing. Shanghai, Jiangsu Province, these universities have greater support for the library, the library is more balanced in all aspects, and can meet the daily needs of teachers and students. While in the central and western regions, only Wuhan University, Huazhong University of Science and Technology and Sichuan University perform well, other colleges and universities need to strengthen financial support; (3) There is a big gap between different types of universities, normal university libraries (Beijing Normal University and East China Normal University) are under rapid development, the library hardware facilities can meet the needs of teachers and students for scientific research. Meanwhile, their support for library is great with the total annual expenditure ranking in the forefront, other types of colleges and universities have no obvious distribution characteristics; (4) Some universities' ranking is relatively backward, which do not match their research and teaching capabilities, such as Tsinghua University. Although Tsinghua University Library has strong scientific research strength and has published many papers, its number of students is large and the number of seats in the library is small. This may also be related to the lack of scientific selection of indicators.

Table 3 The matrix of socre 1

\begin{tabular}{cccccccc}
\hline variable & prin1 & prin 2 & prin 3 & prin 4 & prin 5 & prin 6 & prin 7 \\
\hline 1 & 0.222 & -0.379 & -0.144 & 0.123 & 0.125 & -0.196 & 0.352 \\
2 & 0.302 & -0.280 & -0.303 & -0.166 & -0.009 & -0.008 & 0.330 \\
3 & 0.319 & 0.147 & -0.036 & 0.367 & 0.049 & 0.496 & -0.167 \\
4 & 0.373 & 0.142 & -0.002 & -0.023 & 0.035 & -0.229 & -0.401 \\
5 & 0.327 & 0.337 & -0.259 & 0.058 & 0.003 & 0.159 & -0.018 \\
6 & 0.298 & 0.273 & -0.374 & -0.045 & -0.201 & 0.099 & 0.117 \\
7 & -0.034 & -0.076 & -0.004 & 0.806 & 0.361 & -0.199 & 0.041 \\
8 & 0.113 & 0.467 & 0.256 & 0.055 & -0.050 & -0.252 & 0.650 \\
9 & -0.058 & 0.100 & -0.236 & -0.351 & 0.844 & 0.055 & 0.056 \\
10 & 0.327 & -0.049 & 0.287 & -0.107 & -0.038 & -0.455 & -0.134 \\
11 & 0.379 & -0.149 & -0.141 & -0.087 & 0.099 & -0.279 & -0.278 \\
12 & 0.286 & 0.133 & 0.403 & -0.130 & 0.142 & 0.219 & 0.116 \\
13 & 0.160 & -0.164 & 0.560 & -0.059 & 0.194 & 0.331 & 0.038 \\
14 & 0.220 & -0.495 & -0.019 & -0.003 & -0.159 & 0.282 & 0.164 \\
\hline
\end{tabular}

Published by Francis Academic Press, UK 
Academic Journal of Humanities \& Social Sciences ISSN 2616-5783 Vol. 1, Issue 1: 13-22, DOI: 10.25236/AJHSS.040003

Table 4 The matrix of socre 2

\begin{tabular}{cccccccc}
\hline variable & prin 8 & prin 9 & prin 10 & prin 11 & prin 12 & prin 13 & prin 14 \\
\hline 1 & -0.753 & 0.008 & -0.048 & -0.102 & 0.055 & 0.098 & -0.004 \\
2 & 0.294 & -0.044 & -0.104 & 0.393 & -0.516 & -0.275 & 0.084 \\
3 & -0.807 & 0.019 & -0.099 & -0.437 & -0.409 & -0.017 & 0.298 \\
4 & -0.147 & 0.042 & 0.465 & 0.413 & -0.024 & 0.224 & 0.405 \\
5 & -0.131 & 0.003 & 0.029 & 0.116 & 0.455 & -0.647 & -0.161 \\
6 & 0.118 & 0.139 & -0.384 & 0.106 & 0.198 & 0.614 & -0.151 \\
7 & 0.289 & -0.089 & -0.051 & 0.224 & 0.105 & 0.066 & -0.113 \\
8 & 0.124 & 0.226 & 0.292 & -0.120 & -0.069 & -0.006 & 0.130 \\
9 & 0.112 & 0.0004 & -0.001 & -0.158 & 0.110 & 0.084 & 0.175 \\
10 & 0.153 & -0.211 & -0.538 & -0.218 & 0.185 & -0.142 & 0.332 \\
11 & 0.163 & 0.299 & 0.200 & -0.352 & -0.170 & -0.006 & -0.594 \\
12 & -0.072 & -0.673 & 0.081 & 0.123 & -0.081 & 0.161 & -0.357 \\
13 & -0.041 & 0.567 & -0.215 & 0.318 & 0.106 & -0.014 & -0.199 \\
14 & 0.345 & -0.095 & 0.376 & -0.216 & 0.456 & 0.103 & 0.199 \\
\hline
\end{tabular}

Table 5 Ranking of "double-first class" University Library Support Ability Measurement

\begin{tabular}{|c|c|c|c|c|c|}
\hline University & Score & Rank & University & Score & Rank \\
\hline Zhongshan University & 8791372 & 1 & Jilin University & 2687930 & 22 \\
\hline Fudan University & 7951467 & 2 & $\begin{array}{c}\text { Northwestern Polytechnical } \\
\text { University }\end{array}$ & 2636715 & 23 \\
\hline Wuhan University & 7762838 & 3 & $\begin{array}{l}\text { National University of } \\
\text { Defense Technology }\end{array}$ & 2505276 & 24 \\
\hline Beijing University & 6624861 & 4 & Renmin University of China & 2474998 & 25 \\
\hline Zhejiang University & 6439945 & 5 & Nankai University & 2433219 & 26 \\
\hline Beijing Normal University & 5504325 & 6 & Ocean University of China & 2430029 & 27 \\
\hline East China Normal University & 54286345 & 7 & Jilin University & 24085055 & 28 \\
\hline Sichuan University & 53825935 & 8 & $\begin{array}{l}\text { Harbin Institute of } \\
\text { Technology }\end{array}$ & 2269509 & 29 \\
\hline $\begin{array}{l}\text { Huazhong University of Science } \\
\text { and Technology }\end{array}$ & 50144395 & 9 & Zhengzhou University & 21541547 & 30 \\
\hline Nanjing University & 48167745 & 10 & $\begin{array}{l}\text { China Agricultural } \\
\text { University }\end{array}$ & 2147475 & 31 \\
\hline Southeast University & 4399047 & 11 & Northwest A\&F University & 2146426 & 32 \\
\hline Xi'an Jiaotong University & 4235625 & 12 & Lanzhou University & 2082711 & 33 \\
\hline Shanghai Jiao Tong University & 4095997 & 13 & $\begin{array}{l}\text { University of Science and } \\
\text { Technology of China }\end{array}$ & 1959878 & 34 \\
\hline Tongji University & 3607840 & 14 & Hunan University & 19343288 & 35 \\
\hline Northeastern University & 3456607 & 15 & Yunnan University & 1700347 & 36 \\
\hline Central South University & 3330853 & 16 & Shandong University & 1651697 & 37 \\
\hline $\begin{array}{c}\text { Northwestern Polytechnical } \\
\text { University }\end{array}$ & 3090688 & 17 & $\begin{array}{l}\text { Beijing Institute of } \\
\text { Technology }\end{array}$ & 1557905 & 38 \\
\hline Xiamen University & 3042478 & 18 & $\begin{array}{l}\text { Dalian University of } \\
\text { Technology }\end{array}$ & 1358392 & 39 \\
\hline $\begin{array}{c}\text { University Of Electronic } \\
\text { Science And Technology Of } \\
\text { China }\end{array}$ & 2967051 & 19 & Minzu University of China & 1234691 & 40 \\
\hline Chongqing University & 2952488 & 20 & Tsinghua University & 616628 & 41 \\
\hline Beihang University & 2921313 & 21 & Xinjiang University & 117 & 42 \\
\hline
\end{tabular}

Published by Francis Academic Press, UK 


\subsection{Results of cluster analysis}

According to the results of cluster analysis, it could be seen from Table 6 that the "double-first class" universities and colleges can be divided into four categories by the library supporting ability: (1) Class I. The utilization efficiency of these 10 university libraries is in the forefront of all the double-first class universities and colleges. It provides a large amount of financial support for the library's infrastructure and resource purchase. Facility development and resource development along with each other, while meeting the needs of teachers and students, it also enhances its scientific research strength. Most of these university libraries have an area of 50,000-60,000 square meters, with an annual total funding of 40 million yuan, an average of 5,000 seats, an average of 5.5 million paper resources, and more than 300 Chinese and foreign databases. The human resources, material resources and financial resources invested by these schools are well transformed into teaching, scientific research, and library resources construction. And their utilization efficiency is the leader of the country. (2) Class II, the utilization efficiency of these 30 university libraries is similar to each other. Universities and colleges have also invested a large amount of funds to support the development of libraries, but they have not paid attention to the simultaneous development of facilities construction and resource construction. Their resource input, teaching and research output are at a medium level, and there is a mismatch between these two. The purchase fee of literature resources is more than 14 to 30 million yuan, the total annual expenditure is more than 25 to 32 million yuan, the number of seats is about 3,000, and the amount of paper resources is between 2 million and 5 million. (3) Class III and Class IV are special universities and colleges with an average area of 30,000 square meters. The purchase fee of electronic resources and paper resources are about 5 million yuan, the purchase fee of literature is about 27 million yuan. And the total annual expenditure is about 26 million yuan, basically meet the daily needs of teachers and students. The resource input is mainly transformed into the infrastructure construction, which has not been completely transformed into the teaching \& research needs [8], and the library efficiency needs to be improved. 
Table 6 Classification of Supporting Capabilities of "Double-First Class" University Libraries

\begin{tabular}{|c|c|}
\hline Category & Name of university and college \\
\hline Class I & $\begin{array}{l}\text { Peking University, Beijing Normal University, Fudan University, East } \\
\text { China Normal University, Shanghai Jiaotong University, Huazhong } \\
\text { University of Science and Technology, Zhejiang University, Sichuan } \\
\text { University, Wuhan University, Zhongshan University }\end{array}$ \\
\hline Class II & $\begin{array}{l}\text { Renmin University of China, Tianjin University, Harbin Institute of } \\
\text { Technology, University of Science and Technology of China, } \\
\text { Northwest A\&F University, Northwestern Polytechnical University, } \\
\text { Northeastern University, Hunan University, South China University of } \\
\text { Technology, Chongqing University, Lanzhou University, Yunnan } \\
\text { University, Ocean University of China, Central South University } \\
\text { Nanjing University, Southeast University, Xi'an Jiaotong University, } \\
\text { Tongji University, Beijing University of Aeronautics, China } \\
\text { Agricultural University, Nankai University, University of Electronic } \\
\text { Science and Technology, Beijing Institute of Technology, Dalian } \\
\text { University of Technology, Zhengzhou University, Tsinghua University, } \\
\text { Xinjiang University, Jilin University, Shandong University, Xiamen } \\
\text { University }\end{array}$ \\
\hline Class III & Minzu University of China \\
\hline Class IV & National University of Defense Technology \\
\hline
\end{tabular}

\section{Conclusions and Recommendations}

This paper uses principal component analysis and cluster analysis method to evaluate and compare the library support ability of 42 "double-first class" universities and colleges. The results show that (1) The main factors affecting the library support capacity are the number of staff members, the purchase fee of electronic resources, paper resources, literature resources, the number of published paper and the number of paper resources; (2) The gap in the utilization efficiency of university libraries in different regions is large, showing a stepped distribution in the eastern, central and western regions; (3) Different types of university libraries has obvious utilization efficiency gap. The performance of the library support ability of the normal colleges is excellent. (4) The unbalanced strength of the university libraries' own leads to the inefficiency of the library, and the strength of some university libraries is not matched with the scientific research strength. (5) The main reasons that restrict the efficiency of the university libraries is whether the capital investment has a higher return and whether the libraries' own construction is matched with education and scientific research strength.

The author thinks that the support ability of "double-first class" university libraries should be improved from the following aspects: (1) Reasonable allocation of library construction funds. It should be clear about its own shortcomings, starting 
from the main driving factors of efficiency, increase financial support, balance development, improve the efficiency of the library itself and meet the demands of its own universities. All universities and colleges can optimize the proportion of capital investment according to their own shortcomings, appropriately increase the opening time of the library, increase the number of databases, and meet the needs of teachers and students; (2) Increase the capital investment and attention of university libraries. The country should increase financial support and guarantee the supply of educational resources in the central and western regions, pay attention to the enhancement of scientific research capabilities of libraries, and appropriately increase the recruitment of highly educated and highly qualified librarians; (3) Strengthen exchanges and cooperation between university libraries in and between regions. University libraries with higher efficiency in the east should exchange with lower efficient university libraries in the central and western regions or in the same region, to achieve resource sharing and common progress. Carry out one-on-one assistance and cooperation, the eastern university libraries can be docked with the western universities with less development to achieve common progress; (4) Strengthen data statistics work and open it to the public. University libraries should strengthen their own data statistics work, find out the deficiencies in library efficiency construction through data analysis and improve them, so as to improve library efficiency and give teachers and students more help.

\section{Acknowledgments}

This research was financially supported by the China Postdoctoral Science Foundation Project (Grant NO.2017M621622) and supported by "the Fundamental Research Funds for the Central Universities” (Grant NO. 2018B23614).

\section{References}

[1] Lin Kequan, Kuang Wanling, Gao Bo. Study on Correlation between Universities's Research Ability and its Library's Core Competence: Taking China's 211 Project Universities for Example. Library and Information Service, Vol. 58 (2011), No.24, p.5-10.

[2] Jiang Yumei, Tian Jingmei, Li Xinyun. Research on Performance Evaluation of University Libraries Based on CRITIC-TOPSIS Methods, Library Tribune, Vol.2018, No.3, p.1-9.

[3] Qi Yanhong, Li Qianqing.A Comprehensive Evaluation on Major University Libraries in China, Journal of Modern Information, Vol.30 (2010), No.7, p.103106.

[4] Gao Haitao, Xu Kaiying, Li Han. Research on the Evaluation System of University Libraries Based on Super Efficiency DEA, Library and Information Service, Vol.58 (2014), No.5, p.17-21.

[5] Liang Ru, Li Jianxia, Liu Ying, Liu Yun, Sun Xiaoxing. Evaluation Study on Digital Resources Comprehensive Service Ability in University Libraries, Journal of Academic Libraries, Vol.2015, No.2, p.38-46. 
[6] Zhang Guochen. Research on the Correlation Between the Amount of Digital Resource with Teaching and Researching in University Library--Take Domestic Finance and Economics Universities for Example, Library and Information Service, Vol. 55 (2011), No.7, p.90-93.

[7] Zhao Yinghong. Assessment and Countermeasure of University Library Competitiveness Based on Empirical Research of 52 Universities, Journal of Academic Libraries, Vol. 2011, No.4, p.38-44.

[8] Sun Zhijing, Tian jingmei, Li Xinyun. Research on Performance Evaluation of University Library Construction to Academic Discipline Development in the "Input-Output" Perspective — Based on Universities under the Direct Supervision of Ministry of Education, Library Tribune, Vol. 2016, No.5, p.63-71. 